\title{
Coaching as a global approach to the development of skills in various fields including HORECA and academics
}

\author{
Peter Seemann ${ }^{1, *}$, and Zuzana Stofkova ${ }^{1}$ \\ ${ }^{1}$ University of Zilina, Faculty of Operation and Economics of Transport and Communications, \\ Univerzitna 1, 01026 Zilina, Slovakia
}

\begin{abstract}
Research background: The paper deals with coaching as one of the methods of developing a manager's personality in many fields including the Horeca sector and academics. Academic field also faces challenges like decreasing number of applicants, little application of graduates in the studied fields and quality of education process too.

Purpose of the article: The aim of the research was to analyze the awareness and interest in the coaching approach in the HoReCa sector. The purpose was to find out whether managers perceive the existence of coaching as one of the possible approaches to the development of a person's personality. Furthermore we wanted to show the possibilities to embody coaching approach also to academic field.

Methods: Within the research for quantitative survey methods, a questionnaire is most often used, in which it is important to obtain the necessary number of answers from respondents. Other methods belonging to this group are experiment or observation. An interview was used in the article as well as analysis of current coaching activities in academia.

Findings \& Value added: From the achieved results of the questionnaire survey, it is possible to confirm several facts. It was found that the interest in coaching approach among managers in the HoReCa sector is present because more than half of the respondents answered in the affirmative, i.e. that they are interested in coaching. Respondents clearly think that coaching is a suitable method of developing a manager's personality. Some coaching activities e.g., workshops also took place in the academic field.
\end{abstract}

Keywords: coaching approach; coaching; coach; manager; HoReCa sector.

JEL Classification: $M 12 ; M 54 ; A 14$

\footnotetext{
*Corresponding author : peter.seemann@,fpedas.uniza.sk
} 


\section{Introduction}

Global Coaching inspires managers and coaches to find meaningful and long-lasting results through an integrated approach, combining coaching strategies from physical, managerial, psychological, cultural, political and spiritual perspectives (Rosinski, 2010).

The HoReCa sector is one of the sectors that was less supported by the state. In the current era of Covid-19, many surveys have been conducted, focusing on the functioning of hotels, catering facilities and tourism during this crisis. Many hotels and other facilities have had to lay off their employees or have been forced to close for some time.

Agarwal (2021) in his study, which focused on the impact of the Covid-19 pandemic on the management of human resources in hotels and catering establishments, points to the current situation in these companies. He works with the idea of using this situation for a possible change in human resource management. The possibility of training aimed at increasing employee motivation, improving the psychological side of employees and many other factors proved to be a suitable alternative (Araujo et. al., 2016), (Ashraf et. al., 2020).

In order for a device of this type to function properly, certain principles and rules must be observed Bartanen and Grissom, (2021). Effective business in catering and accommodation facilities is not possible without the application of effective management methods (Cilliers et. al., 2020), (Farkasova and Lizbetinova, 2016).

To operate this type of facility, it is necessary to build a quality team of workers led by management, who can manage efficiently, thoroughly, accurately Feldman and Lankau, 2005), (Stofkova et. al., 2014).

. Management is a dynamic phenomenon; one-time knowledge is not enough. It is necessary for the entrepreneur to monitor the development and application of management to the company's systems (Haggard et. al., 2010), (Jensen, 2010).

Accommodation, catering and service facilities will also progress according to the managers they will have (Kampa-Kokesch and Anderson, 2001). Certain skills are required to perform managerial activities. These skills are referred to as managerial skills (competencies) and directly affect the results of managerial work (Liu, Greenbaum et. al., 2021), (Stofkova and Stofkova, 2010).

Traits, personality traits, skills and the very knowledge they have are an important factor (Ližbetinová et. al., 2020), (Lomas, 2019), (Lundin et. al., 2021).

How they will lead their subordinates, their team and the team as a whole in the workplace. (Matsuo, 2018), (Micieta et. al. 2019).

The way they will provide planning and organizing. Despite all these facts, the personality of the manager is dominant for the operation of the entire company. (Micieta et. al., 2019).

(Nedeliakova, et. al., 2020), (Oreopoulos and Petronijevic, 2018), (Oreopoulos et. al., 2019). The personality of a person and at the same time a manager influences his work performance and the way of performing his profession (Stoermer et. al., 2021), (Belas et. al., 2020), (Bulanda et. al., 2020).

There are many models describing the characteristics and characteristics of a person's personality, but one of the most famous is The Five Factor Model (FFM) (Howard et. al., 2020), (Malkawi and Khayrullina, 2021), (Scott et. al., 2020). (Zygmunt, 2020).

FFM is a hierarchical taxonomy of personality traits organized around five broad dimensions. While the lower levels of this taxonomy are only partially explored, the highest order level is composed of the superordinate factors labelled Extraversion, Agreeableness, Conscientiousness, Emotional Stability (vs Neuroticism), and Intellect (or Openness). 


\section{Methods}

This section contains an analysis of awareness and interest in the coaching approach in the Horeca sector and a closer look at the methods used to determine the results of this analysis.

Directors, managers in the Horeca sector had to take certain measures, such as suspend the work of most of its employees, suspend business partnerships or the supply of necessary raw materials and reduce their costs to the lowest possible level. Such decisions create pressure and stress for all employees, whether superiors or subordinates.

The aim of the practical part was to analyse the awareness and interest in the coaching approach in the HoReCa sector. It was necessary to find out whether managers perceive the existence of coaching as one of the possible approaches to the development of a person's personality. The method we used in this section was a questionnaire survey designed for managers in the HoReCa sector and an online interview.

The questionnaire is one of the methods used to analyse a particular issue. With the help of a questionnaire, it is possible to address a larger number of respondents and at the same time obtain the required number of answers.

With the help of interviews, it is possible to penetrate together with the respondent into the depth of the given issue and thus to clarify more and focus on details. The interview can take various forms, e.g., in person, online or in some cases by phone.

The sample of respondents consisted of managers of hotels, boarding houses and restaurants in the Žilina Region (Slovakia). It focused on higher category hotels, e.g., threestar, four-star and five-star hotels, boarding houses, and restaurants. The questionnaire was intended for managers of these operations. Some of these operations have been suspended due to the current pandemic situation, which has been reflected in the number of responses received.

\section{Results}

The questionnaire consisted of a total of 19 questions. We contacted 85 companies. A total of 41 responses were returned to us, which in percentage terms represents $48.24 \%$. One of the questions was focused on the respondents' opinion on whether coaching is a suitable method of developing a manager's personality. Most respondents expressed a positive opinion and considered coaching as a suitable method of developing a manager's personality in the HoReCa sector.

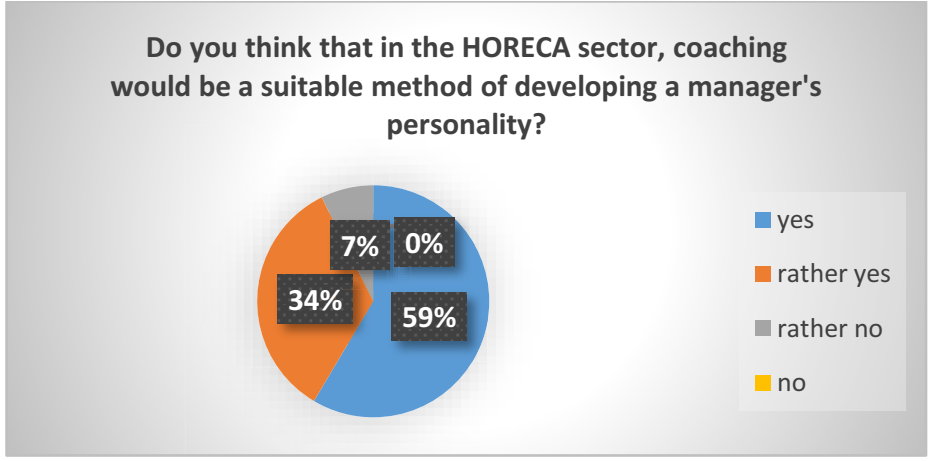

Figure. 1. Coaching as suitable method for developing a manager's personality.

Source: Own Processing.

In the next selected question, we were interested in what managers would expect from applying the coaching method in their companies or departments. 


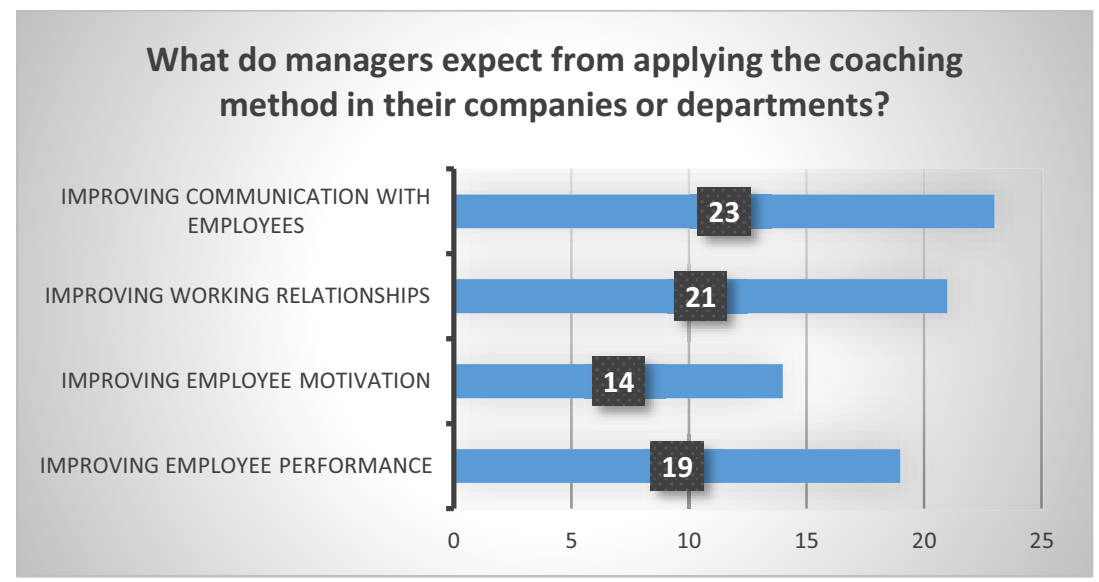

Figure. 2. Benefits that manager expect from the application of the coaching method.

Source: Own Processing.

Another question was with the choice of several options, where the respondents could choose more than one answer. The question was focused on specific management methods and their use in the company.

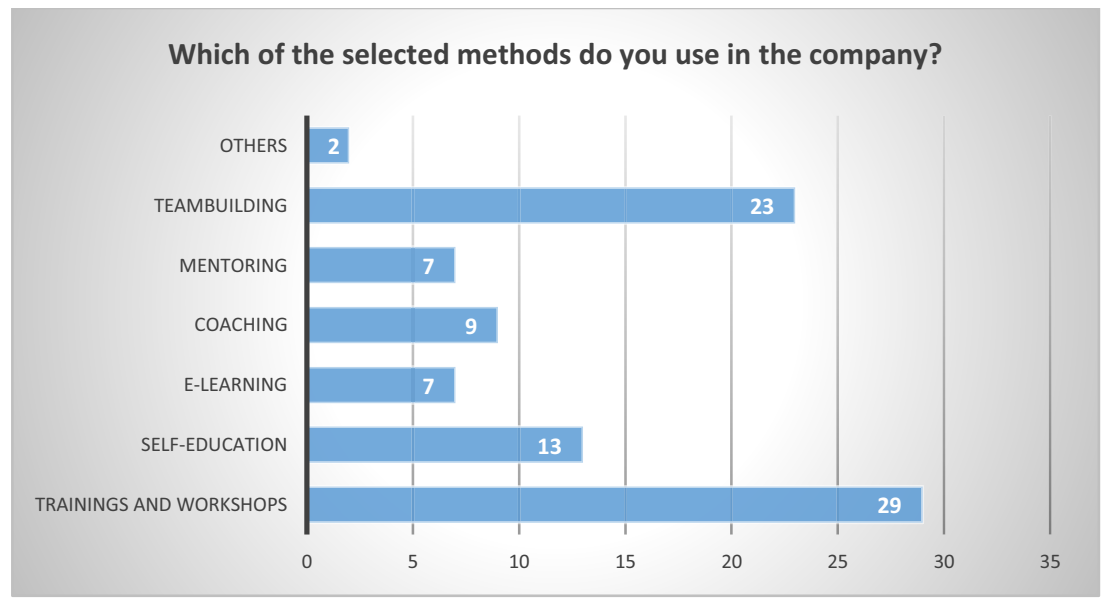

Figure. 3. Benefits that manager expect from the application of the coaching method.

Source: Own Processing.

The most marked response (29) was the training response. The second most called (23) was teambuilding and the third most called (13) was self-education. It is trainings and trainings together with teambuilding that are among the most common forms of education, which has also been confirmed in our research. Coaching as one of the options has been identified nine times. Other options were marked 7 or less times.

The mission of the Initiative for the Introduction of the Coaching Approach to Higher Education Institutions is to realize a long-term vision so that the coaching approach can be used consciously and purposefully at Slovak colleges and universities, i.e. j .:

- To be used in democratized and empowered management of universities and colleges

- to be used by teachers in teaching with enhanced pedagogical skills, 
- to give students the opportunity to acquire coaching skills to use it directly in communication not only after graduation,

- to enable teachers and students to be developed through coaching,

- $\quad$ and part of the whole process is to strengthen awareness of SAKO and ICF SK as professional authorities in the field of coaching as guarantees of quality.

Why introduce coaching approach to universities? The possibilities of using the coaching approach in practice are extensive:

- $\quad$ vision, mission and strategic planning, implementation of changes,

- specification, preparation and implementation of projects,

- search and selection of employees,

- adaptation and development of employees' competencies,

- meeting management, delegation of tasks, setting priorities,

- evaluation and development interviews, motivation, education,

- teamwork, people management, leadership,

- communication in the company (passing on information, constructive solutions, improving relationships and corporate culture),

- external communication (specification of requirements, negotiation of contractual conditions, maintenance of relations, resolution of complaints), etc.

For school management, school staff, students of all levels, it is possible to implement in following ways:

- Informative workshop (leadership members, coaching demonstrations and the use of the coaching approach in practice),

- Lecture, workshop (teachers and students of a suitable target group),

- Training of coaching skills (for staff, college teachers),

- Coaching dedicated subject (creation of cross school subject syllabi to support the coaching competence of students / graduates),

- Coaching zone (individual development coaching for school staff or students).

Teachers can use the coaching approach to:

- Increase involvement of students in the learning and discussion process,

- bringing experiential elements into teaching,

- better integration of knowledge, skills and practical use,

- creating a space for students to independently discover solutions and responsibilities for their own development,

- facilitate the pedagogical and consultation process,

- greater self-confidence and professionalism.

The coaching approach allows students to:

- greater involvement of students in the issues addressed,

- context, decision making and critical thinking,

- setting goals, discovering one's own procedures,

- ability to communicate in an appropriate way,

- taking responsibility for their knowledge and results,

- strengthening project and strategic thinking,

- development of practical leadership skills and projects,

- greater focus in learning.

\section{Discussion and Conclusions}

In this section are summarized possibilities of application of coaching to the development of managers in the Horeca sector and field of academics. 


\subsection{Summary of the questionnaire survey}

Based on the questionnaire survey, it can be concluded that there is an awareness of the coaching approach among managers in the HoReCa sector. Most of the respondents who completed the questionnaire have in some way already encountered a coaching approach. Whether it was based on reviews or recommendations from colleagues and acquaintances, or they encountered the term during their studies, or they have already acted in one of the roles of coach or coachee. The survey also shows that more than half of the respondents would be interested in a coaching approach.

Every manager included in survey is aware of the essence of development and training even during his career, and therefore unanimously agreed that continuous education and development of work potential is important for the proper implementation of a managerial position.

The survey clearly shows that each of the respondents who experienced coaching in person has only a positive experience. They have achieved visible results in management process, which they consider to be much more effective, in improving communication as well as in solving problems.

There are several possibilities to use coaching in Slovakia. It can be individual coaching as well as group and team coaching. There are several organizations of professional coaches operating in our territory, which organize various events, "tastings" of coaching, sessions or webinars, in which the manager can participate without a binding consent to experience the coaching approach. Therefore, we propose to participate in such an event, where it is possible to obtain all the necessary information for the future decision to utilise this method, which managers can apply in the field of improving working relationships, communication or meeting goals.

\subsection{Summary of the interview}

During the interview, we addressed a selected coach and at the same time a manager working in the HoReCa sector. The meeting took place online. This manager (coach) is a graduated hotelier and has been working in the HoReCa sector for several years. He also acts as a professional coach. Before returning to the hotel industry, she worked in other jobs, which enabled her to apply other, new processes from other industries in hotel management. One such process is the coaching approach. Thanks to coaching, they were able to change and create new strategies, gain new perspectives on the matter, they were able to connect their experiences with each other.

Her first meeting with coaching was when she took up a new job. Until then, she had not encountered coaching, and it was thanks to this job position that she came into contact with this concept for the first time. Firstly, she had no idea what coaching was all about. She completed basic training in order to get acquainted with the coaching approach. After completing the training, her main task was to ask "strong" open-ended questions and interview her subordinate employee, who was in the position of salesman. The way in which the manager conducted these interviews led to the fact that traders began to perceive more the possibilities of how things can be done, they perceived the essence of products, services, but especially the communication itself. And all this has led to her interest in coaching also increasing.

As she claims, the coaching approach as a manager gave her a lot. The position of manager in the HoReCa sector is associated with a number of responsibilities for leading and managing employees, taking care of the hotel, customers and their needs and much more. This is indicated by the fact, which she herself confirmed, that this sector is to a large extent connected with emotions. And it was the coaching approach that helped her in managing emotions. You can also serve food from common ingredients on a cheaper plate, but in a way 
that reveals the emotion of joy, enthusiasm and interest in the guest. It follows to me that it is important to show people the true emotion of service, to teach them how to deal with obstacles. And service is ultimately the emotions you can convey.

Based on the manager's record, the manager should be able to work with the emotions of his employees, helping them to understand what it is all about. And it is precisely when it comes to managing emotions that applying a coaching approach is the right choice.

Working with people is one of the hardest jobs. In order to perform their work thoroughly and professionally, it is necessary to motivate employees in the right way. And here is another advantage of coaching.

\subsection{Suggestions and recommendations}

There are a large number of hotels in the Žilina Region, which, despite the problems they have had to face as a result of the situation surrounding the Covid-19 pandemic, plan to reopen their businesses. We assume that after the resumption of operations of hotels and services,

hotels and guesthouses will be able to set aside staff who will be able to take a coaching course. From the point of view of the current pandemic situation, it is not easy to organize coaching courses and sessions in person. When managers take the step to allow employees to express themselves, they also increase employees' motivation to do what they have proposed under the supervision of managers. And for managers, this means they will have more time for strategic tasks and less attention to operational management and micromanagement.

The company would save money on job interviews, vacancy notices, and training that new employee would have to undergo. In this way, the company would keep its employees in the jobs.

Based on the interest of managers working in the HoReCa sector and the manager's experience with a coaching approach in this sector, we would recommend hotels, guesthouses and restaurants to be interested in how to learn how to use the coaching approach.

The benefits of the coaching approach are, in particular, the greater potential of employees, greater degree of independence and personal responsibility, streamlining the planning process, greater commitment to achieving goals, promoting high work performance in the team, improving communication and working relationships.

- The reasons that require changes in the business environment are in particular:

- Shift from long-term employment to short-term projects,

- Project teams of specialists with qualifications and experience,

- Changing the role of leaders, agile approach

There are demands for change to higher education:

- Development of practical abilities and skills of academic managers, could lead to more effective leadership, open communication, and faster accommodation to the needs of the target (job market)

- Improving the teacher skills with the use of coaching approach could result to more enjoyable lectures and more close cooperation between students and teachers based on a principle of partnership.

- Providing these unique coaching skills to students could lead to completely new communication and leadership style especially applicable yet during the study period in their problem solving on school projects, temporary jobs, student organizations activity etc. This concept is mostly usable for the students of management field; however each field could profit out of this new set of skills. The students will once join the managers who utilise coaching in their work in HoReCa 
and other fields, could possess the skills yet at school and use them from the very beginning of their managerial career.

There is a high potential in bringing the coaching approach, and coaching skills in the academic environment and The University of Zilina is at the beginning of this path along with lots of colleges and universities in Slovakia involved in the project "Because we care" by the Slovak Association of Coaches, and the Slovak chapter of the International Coach Federation.

\section{Acknowledgements}

This work was supported by project KEGA 043ŽU-4/2019, KEGA 052ŽU-4/2021

\section{References}

1. Agarwal, P. (2021). Shattered but smiling: Human resource management and the wellbeing of hotel employees during COVID-19. International Journal of Hospitality Management, 93, 102765.

2. Araujo, M. C., Carneiro, P., Cruz-Aguayo, Y., \& Schady, N. (2016). Teacher quality and learning outcomes in kindergarten. The Quarterly Journal of Economics, 131(3), 14151453.

3. Ashraf, N., Bau, N., Low, C., \& McGinn, K. (2020). Negotiating a better future: How interpersonal skills facilitate intergenerational investment. The Quarterly Journal of Economics, 135(2), 1095-1151.

4. Bartanen, B., \& Grissom, J. A. (2021). School Principal Race, Teacher Racial Diversity, and Student Achievement. Journal of Human Resources, 0218-9328R2.

5. Belas, J., Gavurova, B., Schonfeld, J., Zvarikova, K., \& Kacerauskas, T. 2017.Social and economic factors affecting the entrepreneurial intention of university students. Transformations in Business \& Economics, 16(3), 220-239.

6. Bell, E. (2020). Cognitive Automation, Business Process Optimization, and Sustainable Industrial Value Creation in Artificial Intelligence Data-driven Internet of Things Systems. Journal of Self-Governance and Management Economics, 8(3), 9-15.

7. Bulanda, I., Kadekova, Z, Kosiciarova, I., \& Vavrecka, V. (2020). The perception of commercial and social advertising by the generation $\mathrm{Y}$ in the Czech Republic. Ekonomicko-manazerske spektrum, 14(2), 63-77

8. Cilliers, J., Fleisch, B., Prinsloo, C., \& Taylor, S. (2020). How to improve teaching practice? An experimental comparison of centralized training and in-classroom coaching. Journal of Human Resources, 55(3), 926-962.

9. Farkasova, V., \& Lizbetinova, L. (2016). Kariera ako sucast rozvoja osobnosti. EDIS.

10. Feldman, D. C., \& Lankau, M. J. (2005). Executive coaching: A review and agenda for future research. Journal of management, 31(6), 829-848.

11. Haggard, D. L., Dougherty, T. W., Turban, D. B., \& Wilbanks, J. E. (2011). Who is a mentor? A review of evolving definitions and implications for research. Journal of management, 37(1), 280-304.

12. Howard, F., Kral, P., Janoskova, K., \& Suler, P. (2020). Risk Perception and Societal Acceptance of Autonomous Vehicle Technologies. Contemporary Readings in Law and Social Justice, 12(1), 44-50. 
13. Jensen, R. (2010). The (perceived) returns to education and the demand for schooling. The Quarterly Journal of Economics, 125(2), 515-548.

14. Kampa-Kokesch, S., \& Anderson, M. Z. (2001). Executive coaching: A comprehensive review of the literature. Consulting Psychology Journal: Practice and Research, 53(4), 205.

15. Liu, X., Greenbaum, R. L., Allen, D., \& Zhang, Z. (2021). A Newcomer Socialization Perspective on the Proliferation of Unethical Conduct in Organizations: The Influences of Peer Coaching Practices and Newcomers' Goal Orientations. Journal of Business Ethics, 1-16.

16. Ližbetinová, L., Hitka, M., Soušek, R., \& Caha, Z. (2020). Motivational preferences within job positions are different: empirical study from the Czech transport and logistics enterprises. Economic Research-Ekonomska Istraživanja, 1-21.

17. Lomas, T. (2019). Positive work: a multidimensional overview and analysis of workrelated drivers of wellbeing. International Journal of Applied Positive Psychology, 3(1), 69-96.

18. Lundin, M., Skans, O. N., \& Zetterberg, P. (2021). Leadership experiences, labor market entry, and early career trajectories. Journal of Human Resources, 56(2), 480-511.

19. Malkawi, E., \& Khayrullina, M. (2021). Digital human skills from the corporate economy and business development. Ekonomicko-manazerske spektrum, 15(1), 64-74.

20. Matsuo, M. (2018). How does managerial coaching affect individual learning? The mediating roles of team and individual reflexivity. Personnel review.

21. Micieta, B., Binasova, V., Lieskovsky, R., Krajcovic, M., \& Dulina, L. (2019). Product segmentation and sustainability in customized assembly with respect to the basic elements of industry 4.0. Sustainability, 11(21), 6057.

22. Micieta, B., Krajcovic, M., \& Binasova, V. (2019). Toward an improved dual learning and lifelong learning in the department of industrial engineering in zilina. In EDULEARN19 Proceedings 11th International Conference on Education and New Learning Technologies: Palma, Spain. 1-3 July, 2019 (pp. 2300-2306). IATED Academy.

23. Nedeliakova, E., Hudakova, M., Masar, M., Lizbetinova, L., Stasiak-Betlejewska, R., \& Šulko, P. (2020). Sustainability of railway undertaking services with lean philosophy in risk management-Case study. Sustainability, 12(13), 5298.

24. Oreopoulos, P., \& Petronijevic, U. (2018). Student coaching: How far can technology go?. Journal of Human Resources, 53(2), 299-329.

25. Oreopoulos, P., Patterson, R. W., Petronijevic, U., \& Pope, N. G. (2019). Low-touch attempts to improve time management among traditional and online college students. Journal of Human Resources, 0919-10426R1.

26. Rosinski, P. (2010). Global coaching: An integrated approach for long-lasting results. Nicholas Brealey.

27. Scott, R., Poliak, M., Vrbka, J., \& Nica, E. (2020). COVID-19 Response and Recovery in Smart Sustainable City Governance and Management: Data-driven Internet of Things Systems and Machine Learning-based Analytics. Geopolitics, History, and International Relations, 12(2), 16-22.

28. Stoermer, S., Davies, S., \& Froese, F. J. (2021). The influence of expatriate cultural intelligence on organizational embeddedness and knowledge sharing: The moderating effects of host country context. Journal of International Business Studies, 52(3), 432453. 
29. Stofkova, K., \& Stofkova, J. (2010). Implementation of the knowledge management as a competitive advantage, 2nd International Conference on Education and New Learning Technologies, Barcelona, Spain, Jul 05-07, EDULEARN Proceedings, 1323-1328.

30. Stofkova, K., Stofkova, J., \& Stofko, S. (2014). Survey of knowledge management utilization in organizations. 7th International Conference of Education, Research and Innovation, Seville, Spain, Nov 17-19, ICERI Proceedings, (pp. 1725-1729).

31. Zygmunt, J. (2020). The effect of changes in the economic structure on entrepreneurial activity in a transition economy: the case of Poland. Equilibrium. Quarterly Journal of Economics and Economic Policy, 15(1), 49-62. 